\title{
Recent mosasaur discoveries from New Jersey and Delaware, USA: stratigraphy, taphonomy and implications for mosasaur extinction
}

\section{W.B. Gallagher ${ }^{1,2}$}

1 Bureau of Natural History, New Jersey State Museum, Trenton, NJ 08625-0530, USA. Email: william.gallagher@sos.state.nj.us

2 Department of Geological Sciences, Rutgers University, Piscataway, NJ 08855, USA.

Manuscript received: December 2004; accepted: January 2005

\begin{abstract}
The Upper Cretaceous deposits of New Jersey and Delaware produced the first mosasaur specimens collected in North America. Recent recovery of mosasaur specimens from streambank exposures and new excavation sites has increased our knowledge of the stratigraphic distribution of these animals in the northern Atlantic coastal plain. Reassessment of the source and age of mosasaur specimens from the Big Brook site and other localities in Monmouth County (NJ) has greatly increased the number of known Campanian mosasaur specimens from this region. Two main taphonomic occurrence modes are noted: 1 - single, worn and broken bones and isolated teeth in mixed faunal deposits probably accumulated due to current action in nearshore environments; 2 - partial skeletons, skulls and single bones in deeper-water settings were the aftermath of biological modification of carcasses and deadfalls. The mosasaurs of the New Egypt Formation represent some of the last (i.e., stratigraphically highest) mosasaur fossils in North America. Mosasaur extinction was due to the collapse of the rich Late Cretaceous marine food web at the K/T boundary. Subsequently in the early Paleocene, with the disappearance of the mosasaurs, crocodilians became the apical predators of the marine environment in this area.
\end{abstract}

Keywords: Mosasaurs, Late Cretaceous, taphonomy, extinction

\section{Introduction}

After the discovery of mosasaurs in southern Limburg (The Netherlands) in the late eighteenth century, the Atlantic coastal plain of New Jersey was the first area in North America to produce mosasaur remains. In 1818, Mitchill (cited in Russell, 1967) reported the discovery of mosasaur teeth from the Atlantic Highlands along Raritan Bay, across from New York City, which DeKay (1830) elaborated upon and identified as belonging to the genus Mosasaurus Conybeare 1822. Subsequently, Bronn (1838) named this specimen M. dekayi, the type of which is now apparently lost (Russell, 1967); since the specimen consisted of a single tooth crown, the taxon is considered a nomen dubium. In 1830, Samuel Morton of Philadelphia also discussed finds of mosasaur remains in New Jersey in a synopsis of the fossils from the inner coastal plain area. In the ensuing decades of the nineteenth century a series of mosasaur specimens came out of the marl pits of southern New Jersey, mostly described and named by Leidy, Cope and Marsh.

The inner Atlantic coastal plain of New Jersey and Delaware is largely underlain by Campanian and Maastrichtian beds (Fig. 1). Most of these deposits are marine in origin and several of them are rich in the mineral glauconite, which was mined extensively in this region in the nineteenth century. During the course of these mining operations many specimens of fossil vertebrates were recovered, including mosasaurs. The collections of the Academy of Natural Sciences of Philadelphia, the Yale Peabody Museum and the American Museum of Natural History contain numerous remains of mosasaurs from the zenith of marl-mining in New Jersey. Unfortunately, precise stratigraphic and locality data are missing for many of 


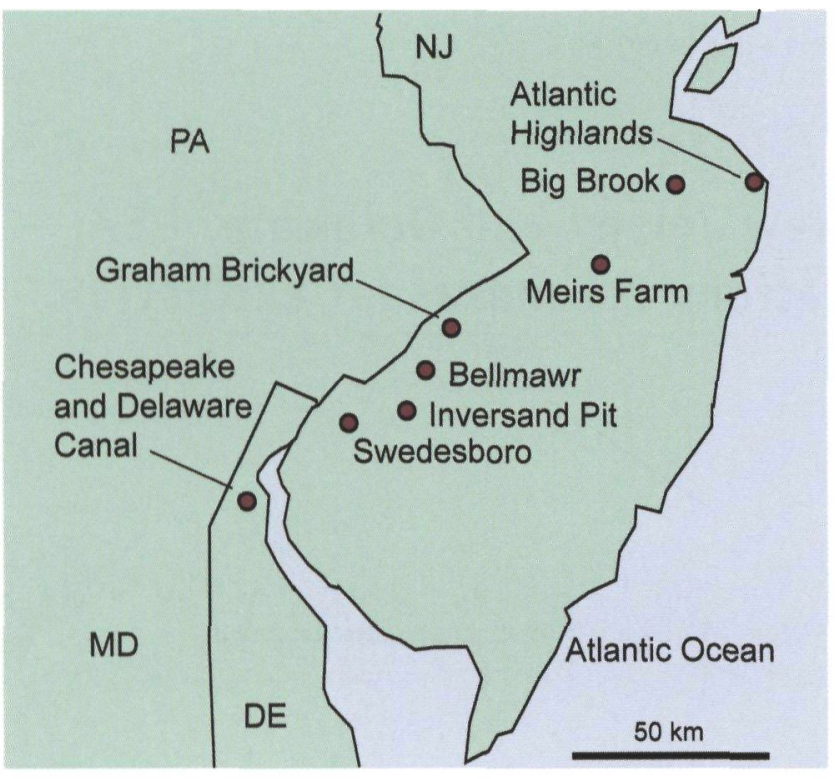

Fig. 1. Map of important mosasaur sites in the Upper Cretaceous outcrop area of the northern Atlantic coastal plain, New Jersey and Delaware. Abbreviations: DE - Delaware; NJ - New Jersey; MD - Maryland; PA - Pennsylvania.

these specimens. An additional difficulty is that some of the mosasaur material in older collections suffers from pyrite disease, and this may account for missing type and illustrated specimens. The salvage of vertebrate fossils, including mosasaurs, continues in New Jersey and Delaware today as widespread excavations and streambank exposures yield new specimens. The present paper reports on some of the more recent discoveries, and places mosasaur specimens from this region in an updated stratigraphic context (Table 1 ).

Table 1. Stratigraphic distribution of mosasaur taxa in the Upper Cretaceous deposits of the North Atlantic coastal plain, Delaware and New Jersey

\begin{tabular}{|c|c|c|}
\hline Stage & Formation & Mosasaur taxa \\
\hline Danian & Hornerstown & Mosasaurus sp. \\
\hline Maastrichtian & New Egypt & Mosasaurus cf. hoffmanni \\
\hline Maastrichtian & Tinton & - \\
\hline Maastrichtian & Red Bank & - \\
\hline Maastrichtian & Navesink & $\begin{array}{l}\text { M. hoffmanni, M. conodon, M. dekayi }{ }^{\star} \text {, } \\
\text { Prognathodon rapax, Halisaurus } \\
\text { platyspondylus, Leiodon sp. }\end{array}$ \\
\hline Campanian & Mount Laurel & $\begin{array}{l}\text { Mosasaurus sp., M. dekayi }{ }^{\star} \text {, Leiodon sp., } \\
\text { Prognathodon sp., plioplatecarpine? }\end{array}$ \\
\hline Campanian & Wenonah & - \\
\hline Campanian & Marshalltown & $\begin{array}{l}\text { Clidastes iguanavus, Globidens sp., } \\
\text { Mosasaurus sp. }\end{array}$ \\
\hline Campanian & Englishtown & - \\
\hline Campanian & Woodbury & Clidastes sp. \\
\hline Campanian & Merchantville & $\begin{array}{l}\text { Plioplatecarpus sp., Clidastes sp., } \\
\text { Mosasaurus sp. }\end{array}$ \\
\hline
\end{tabular}

\footnotetext{
* Nomen dubium
}

\section{Abbreviations}

ANSP - Academy of Natural Sciences, Philadelphia; MAPS Monmouth Amateur Paleontological Society; NJSM - New Jersey State Museum; YPM - Yale Peabody Museum.

\section{Campanian mosasaur discoveries}

The earliest mosasaur remains from this area are from the Merchantville Formation of early Campanian age. The mosasaur record from this time is scanty, consisting of rare specimens from but two sites. A set of bones from the Chesapeake and Delaware Canal (C\&D Canal for short) in Delaware is attributed to Plioplatecarpus, and some additional fossils from this area are ascribed to Mosasaurus sp. (Lauginiger, 1988). The Plioplatecarpus material (MAPS A-1207a) consists of two vertebrae plus paddle bones (two metatarsals, plus four phalanges) from the Merchantville Formation in the C\&D Canal at Summit, New Castle County (Delaware). The metatarsals are widely flared at the proximal end, suggesting a broad paddle. Two smaller teeth of mosasaurs from New Jersey are assigned to cf. Clidastes; these (ANSP 21539; NJSM 20657) are from the Merchantville Formation at the old Graham Brickyard site at Maple Shade, Burlington County (NJ), an area that is now an industrial park (Robb, 2004). The teeth are small, and ridged near the base of the crown; both are from the early Campanian Scaphites hippocrepis III ammonite zone, approximately $83.5+$ 0.5 million years old.

Slightly younger mosasaur specimens are known from the overlying Woodbury Formation. Donald Clemens, a private collector, donated two vertebrae and two portions of jaw from the Bellmawr landfill site in Camden County to the New Jersey State Museum. The round vertebrae display the distinctive zygantra-zygosphene articulation characteristic of Clidastes, and are tentatively assigned to this genus on that basis. Stable strontium isotope age estimation done on original bivalve shell from the Woodbury Formation has yielded a date of 78.5 to 80.5 million years (Gallagher et al., 1996).

The Marshalltown Formation of mid-Campanian age has yielded remains of mosasaurs from the banks of the Chesapeake and Delaware Canal in Delaware. Some of the larger teeth are tentatively identified as Mosasaurus sp. Other, smaller, blunt, semi-spherical teeth are assigned to the supposed shell-crusher Globidens sp. Russell (1967) listed only one mosasaur specimen form the Campanian of New Jersey, a single vertebra (YPM 1601) of Clidastes iguanavus from a marl pit located in the vicinity of Swedesboro (Cope, 1869), where the principal source of greensand marl was the Marshalltown Formation. This taxon is based upon non-diagnostic material and so the species name may be considered invalid. 


\section{Big Brook mosasaurs and the Campanian- Maastrichtian boundary}

The brooks and streams of Monmouth County in eastern New Jersey have long been a popular area for collecting Cretaceous vertebrate fossils. Along Big Brook, in Marlboro, Monmouth County, several stratigraphic units are exposed along the steep banks of the brook - the Mount Laurel, Navesink and Red Bank formations. The favourite technique of private collectors working here is to sieve the stream gravels which are an enriched placer deposit of fossils eroded from the surrounding embankments. Sieving stream gravels produces mosasaur teeth and bones (mostly vertebrae) of several genera including Leiodon, Mosasaurus, Prognathodon and a possible plioplatecarpine (ANSP 20183). It has been commonly assumed that the bulk of the specimens are from the very fossiliferous Maastrichtian Navesink Formation, but recent quarrying of the underlying late Campanian Mount Laurel Formation has revealed that this unit is the primary source of the majority of the vertebrate fossils found in the brook gravels.

A thin fossiliferous layer near the top of Mt. Laurel Formation is a major supplier of fossils (Gallagher et al., 2003; in press). Here the material occurs as isolated elements mixed with marine molluscs, crustaceans and land vertebrates. The most abundant fossils in this layer are sharks' teeth, but large reptile bone is a close second. The principal component of the fossil reptile bone is probably mosasaurian; certainly the most abundant reptilian teeth at this horizon are from mosasaurs.

Since many of the vertebrate fossils in the Big Brook gravels were assumed to come out of the Maastrichtian Navesink Formation, but careful excavation of previously inaccessible deposits (Gallagher et al., in press) shows that the primary source for most of the mosasaur material and other vertebrate fossils found in the stream gravels is actually the latest Campanian Mount Laurel Formation, a substantial correction in age assignment for numerous Big Brook bones and teeth is required. This is especially true since the contact between the Mount Laurel and the Navesink is unconformable at Big Brook, Ramannesin Brook, and elsewhere in Monmouth County. This unconformity is essentially the Campanian-Maastrichtian boundary in this region. The unconformity probably represents several million years of missing time (Miller et al., 1999), a significant age readjustment for these well-known and welldocumented localities. As a result of this age reassignment and the correct determination of a source bed for the mosasaur remains in this area, the present report greatly expands the record of Campanian mosasaurs in the northern Atlantic Coastal Plain. From sedimentologic and taphonomic studies, it is inferred that the Mount Laurel Formation fossils were probably concentrated in nearshore deposits as disarticulated, isolated elements (Gallagher et al., 2003; in press).

\section{Maastrichtian mosasaurs}

The Maastrichtian age beds in the northern Atlantic coastal plain have a complex facies relationship that varies along strike and downdip. This is especially true in Monmouth County, where the Maastrichtian section is thicker. Most of the Maastrichtian mosasaur material comes from two formations: the Navesink Formation of earlier Maastrichtian age and the New Egypt Formation of late Maastrichtian age. Interfingering with this last formation are the Red Bank and Tinton formations.

A lower jaw of Mosasaurus is one of the best specimens to have emerged from the basal Navesink Formation at Atlantic Highlands, Monmouth County in recent years. This locality is the site of the now-lost type specimen of $M$. dekayi. The slender construction of the dentary and small conical recurved teeth identify this new specimen as M. conodon (see Russell, 1967, for diagnosis).

The Inversand Company pit in Mantua Township, Gloucester County (NJ) is the only greensand marl mine still in operation. This pit reveals the updip section of the K/T boundary in the southern portion of the outcrop belt. Numerous specimens of isolated teeth, bones and two skulls of mosasaurs have come from here; Russell (1967) used one skull (NJSM 11052) from the pit as the basis for some of his figures of Mosasaurus maximus (now synonymised with $M$. hoffmanni; Mulder, 1999). Most of the best mosasaur material comes from the basal shellbed in the 'Chocolate Marl' or Navesink Formation; this bed has also been assigned to the New Egypt Formation, which it resembles lithologically. More recently, a Leiodon tooth has been recovered from this basal shellbed in the New Egypt (Navesink) Formation. A large portion of the rear mandible of Mosasaurus is also from this level. The chocolate marl produces periodic specimens of Halisaurus platyspondylus, distinguished by flattened, oval vertebral centra twice as wide as high. A set of small pelvic girdle bones probably pertains to this taxon. This is also the horizon that yielded 'Ancylocentrum hungerfordi', a specimen subsequently referred to Prognathodon rapax by Russell (1967).

Usually the greensand mosasaur fossils, even fairly complete skulls, are found disarticulated or as isolated elements. This is probably the result of biological activity; many bones show traces of scavenging, e.g. parallel slash marks. Observations made on bones and turtle shells left in aquaria at the NJSM show that there are a wide variety of biological interactions that result in bone modification in the marine environment, including scavengers, algal scrapers, bone borers like the bivalve Lithophaga, burrowers of substrate below the skeletal remains, inhabitants and colonisers. Observation of whale deadfalls on the ocean bottom show that large marine vertebrate remains become a major site of biological activity which results in the modification, disarticulation and scattering of the skeleton. Such processes can be hypothesised to be responsible for the high taphonomic maturity of New Jersey mosasaur specimens, 
which sat out on low-energy glauconitic substrates that had low sediment input rates, probably for substantial periods of time. Additionally, mosasaur skulls were very loose, open structures, prone to post-mortem disarticulation because of their flexible construction (Staron et al., 2000).

The Navesink Formation here is now known to be late Maastrichtian on the basis of ammonite zonation. Discoscaphites conradi has been found in the Navesink Formation at Inversand, correlating it with the upper part of the Fox Hills Formation in the Western Interior (Gallagher, 1997). This is late (although not latest) Maastrichtian in age.

Elsewhere, the New Egypt Formation has produced even younger, stratigraphically higher ammonites - the Discophites iris Zone at Eatontown and elsewhere in Monmouth County (NJ) is the last ammonite zone in North America (Landman et al., 2004). These higher levels have also produced mosasaur material; isolated mosasaur bones and teeth are known from Eatontown. Lately, a string of seven Mosasaurus vertebrae from Meirs Farm, Hornerstown, Monmouth Co. (NJ) has been dug out from high in the New Egypt Formation. The Meirs farm was historically a source of vertebrate fossils for 0.C. Marsh, and he named $M$. meirsi (now regarded as a synonym of $M$. dekayi) on the basis of a tooth from a marl pit on this farm. The material from the upper reaches of the New Egypt Formation represents some of the youngest, stratigraphically highest mosasaur fossils in North America.

The only mosasaurs that are stratigraphically higher occur in the Hornerstown Formation. The basal Hornerstown Formation has an abundantly fossiliferous horizon sometimes called the Main Fossiliferous Layer, or MFL for short. This bed produces mosasaur remains, but these are usually single isolated bones, often quite worn looking - some of the vertebrae from this layer are quite abraded, for example. So it has been argued that this material is reworked from underlying Cretaceous beds. But there are also mosasaur braincases and fresher-looking teeth as well from the MFL, although these are relatively more durable elements that would be more resistant to damage. A number of other Late Cretaceous fossils are found in this layer, including the shark Sqaulicorax, the teleost Enchodus, and several genera of ammonites. There is some question over the age of this bed - is this a latest Maastrichtian deposit, or is it of early Paleocene age with some reworked Cretaceous fossils in it? The MFL may be a time-averaged remanie deposit, with Cretaceous fossils accumulating under winnowed low sediment circumstances (Gallagher, 1993). An alternative hypothesis for the origin of this bed is that the MFL represents a lag deposit of Cretaceous fossils left in the wake of an impact tsunami, with subsequent input from Paleocene mortality.

\section{Mosasaur extinction}

Large marine animals have broad biogeographic ranges in today's oceans, and the same was probably true of prehistoric marine reptiles such as mosasaurs (Mulder, 1999; Gallagher et al., 2004). This implies that mosasaurs, especially the larger forms, were pelagic animals capable of traversing deep, open ocean waters. Large mosasaur populations may have been affected by widespread regression at the end of the Cretaceous, leading to reduction in habitat area, but it is just as likely that mosasaur populations simply followed the retreating sea and sought refuge in deeper waters. Some other cause must be involved in the disappearance of the mosasaurs; after all, they survived previous regressions, such as the well-documented sea level change of the mid-Campanian.

The disappearance of mosasaurs at the $\mathrm{K} / \mathrm{T}$ boundary is probably due to collapse of the Late Cretaceous marine trophic web. During the Late Cretaceous, plentiful planktonic and shellfish food resources supported an abundant and diverse group of large marine predators. This ecosystem represented the zenith of the Mesozoic marine radiation, with a variety of large oysters and clams, an assortment of ammonites and numerous fish species to support the higher levels of the oceanic food web (Gallagher, 1993).

The crash of plankton populations at the $\mathrm{K} / \mathrm{T}$ boundary affected larger marine predators including mosasaurs. Paleocene marine ecosystems were more oligotrophic- there were fewer food resources available especially in the early part of the epoch. With the disappearance of mosasaurs, crocodilians moved into the niche of large marine predators. There is a 'crocodile spike' in the early Paleocene Hornerstown Formation (Gallagher, 2003), where the commonest large vertebrate fossils are partial skeletons of crocodilians, including Thoracosaurus, Hyposaurus, Diplocynodon and Bottosaurus. While Diplocynodon is known from the Marshalltown Formation (Campanian) in New Jersey, it is only rarely found in the estuarine beds of the Ellisdale site; and Thoracosaurus, while present in the Navesink Formation (Maastrichtian), is not commonly found until the Hornerstown Formation, where it is abundant and well-known from numerous partial skeletons of early Danian age (Gallagher, 1993). Previous to this, it would appear that mosasaurs and crocodilians inhabited different environments in the Late Cretaceous, and so did not directly compete for trophic resources.

\section{Discussion}

New discoveries as well as a reassessment of the age and source of the common mosasaur fossils from the Monmouth County brooks reveal a greater diversity and abundance of Campanian mosasaurs than previously recorded. There appear to be two contrasting taphonomic modes of vertebrate fossil occurrences (including mosasaur remains) in these beds. In the Mount Laurel fossiliferous horizon at Big Brook and elsewhere in Monmouth County, layered concentrations of mixed terrestrial and marine fossils appear to be the result of primarily physical factors such as sea level change and current 
action in nearshore environments. In the deeper-water settings of the more glauconitic units, such as the Navesink Formation, biological modification and disarticulation played an important role in scattering deadfalls and producing partial or single specimens. These taphonomic factors were responsible for producing the partial or isolated single-element specimens on which much of the nineteenth century nomenclature for mosasaurs was based, and this led to some of the long-term difficulties with mosasaur taxonomy that are still being sorted out by present-day workers (e.g., in the case of $M$. dekayi and M. meirsi).

Mosasaurs probably disappeared as a result of the collapse of the long-stable Mesozoic marine ecosystems, as the base of the marine food web, the plankton, suffered severe extinctions at the $\mathrm{K} / \mathrm{T}$ boundary. The mosasaurs appear to have been thriving until late into the Maaastrichtian; their fossils are the commonest amongst larger vertebrates in the New Egypt Formation, the last and latest deposit of the Cretaceous Period in this region. After the disappearance of the mosasaurs, crocodilians radiated into the niche of large marine predator.

\section{Acknowledgements}

I would like to thank the organisers of the First Mosasaur Meeting, Anne S. Schulp and John W. M. Jagt, for an excellent conference. I must express my gratitude to Douwe Th. De Graaf and the staff of the Natuurhistorisch Museum Maastricht for hosting the meeting. Finally my thanks go to Eric Mulder and Marcus Ross for their helpful reviews of this paper.

\section{References}

Bronn, H.G., 1838. Lethaea geognostica, oder Abbildungen und Beschreibung der für die Gebirgs-Formationen bezeichnendsten Versteinerungen, 2. E. Schweizerbart (Stuttgart): 545-1346.

Conybeare, W.D., 1822. In: J. Parkinson (ed.). An Introduction to the study of fossil organic remains. vii +344 pp., London.

Cope, E.D., 1869. On some Cretaceous Reptilia. Proceedings of the Academy of Natural Sciences of Philadelphia 20: 233-242.

DeKay, J.E., 1830. On the remains of extinct reptiles of the genera Mosasaurus and Geosaurus found in the Secondary formation of New Jersey: and on the occurrence of the substance named Coprolite by Dr Buckland, in the same locality. Annals of the Lyceum of Natural History of New York 3: 134-141.

Gallagher, W.B., 1993. The Cretaceous/Tertiary mass extinction event in the northern Atlantic Coastal Plain. The Mosasaur 5: 75-154.

Gallagher, W.B., 1997. New data on old discoveries: reinvestigating East Coast dinosaurs. In: Wolberg, D.L., Stump, E. \& Rosenberg, G. (eds): Dinofest International Symposium Proceedings, Academy of Natural Sciences, Philadelphia: 199-201.

Gallagher, W.B., 2003. Oligotrophic oceans and minimalist organisms: collapse of the Maastrichtian marine ecosystem and Paleocene recovery in the Cretaceous - Tertiary sequence of New Jersey. Netherlands Journal of Geosciences 82: 225-231.
Gallagher, W.B., Sugarman, P.J. \& Feigenson, M.D., 1996. Strontium isotope age estimates for East Coast dinosaur sites. Journal of Vertebrate Paleontology 16 (Suppl, to 3): 36A.

Gallagher, W.B., Parris, D.C., Grandstaff, B.S., Camburn, J. \& Camburn, S., 2003. Comparative taphonomy of vertebrate fossil concentrations in the Late Cretaceous - Early Tertiary sequence of New Jersey. Journal of Vertebrate Paleontology 23 (Suppl. to 3): 53A.

Gallagher, W.B., Jagt, J.W.M., Mulder, E.W.A. \& Schulp, A.S., 2004. A new mosasaur specimen from Maastricht (the Netherlands), with a review of the Late Cretaceous-Early Paleogene marine faunas of New Jersey and Limburg. The Mosasaur 7: 47-57.

Gallagher, W.B., Camburn, J., Camburn S., \& Hanzcaryk, P.A. (In press). Taphonomy of a late Campanian fossil assemblage at Marlboro, Monmouth County, New Jersey. Northeastern Geology and Environmental Science.

Landman, N.H., Johnson, R.O., Cobban, W.A. \& Edwards, L.E., 2004. Cephalopods from the Cretaceous/Tertiary boundary interval on the Atlantic Coastal Plain, with a description of the highest ammonite zones in North America, Part 2. Northeastern Monmouth County, New Jersey. Bulletin of the American Museum of Natural History 287: 1-107.

Lauginiger, E., 1988. Cretaceous fossils from the Chesapeake and Delaware Canal - a guide for students and collectors. Delaware Geological Survey, Special Publication 18: $57 \mathrm{pp}$.

Miller, K.G., Barrera, E., Olsson, R.K., Sugarman, P.S. \& Savin, S.M., 1999. Does ice drive early Maastrichtian eustacy? Geology 27: 783-786.

Mitchill, S.L., 1818. Observations on the geology of North America. In: Cuvier, G.C.P., Essay on the Theory of the Earth (New York): 319-431.

Morton, S.G., 1830. Synopsis of the organic remains of the Ferruginous Sand formation of the United States; with geological remarks. American Journal of Science 17: 274-294; 18: 243-250.

Mulder, E.W.A., 1999. Transatlantic latest Cretaceous mosasaurs (Reptilia, Lacertilia) from the Maastrichtian type area and New Jersey. In: Jagt, J.W.M., Lambers, P.H., Mulder, E.W.A. \& Schulp, A.S. (eds). Proceedings of the Third European Workshop on Vertebrate Paleontology, Maastricht, May 6-9, 1998. Geologie en Mijnbouw 78: 281-300.

Robb, A.J. III, 2004. Vertebrate fossils from the Upper Cretaceous (Merchantville Formation: Early Campanian) Graham Brick Yards locality of New Jersey. The Mosasaur 7: 75-88.

Russell, D.A., 1967. Systematics and morphology of American mosasaurs. Bulletin of the Peabody Musem of Natural History Bulletin, Yale University 23: 1-240.

Staron, R.M., Grandstaff, B.S., Gallagher, W.B. \& Grandstaff, D.E., 2001. REE signatures in vertebrate fossils from Sewell, NJ: Implications for location of the K-T boundary. Palaios 16: 255-265. 